\title{
Możliwość pociągnięcia do odpowiedzialności dziennikarza za opublikowanie informacji o karalności osoby publicznej mimo faktu zatarcia tej karalności ${ }^{1}$
}

\begin{abstract}
Zdaniem autorki opinii zatarcie skazania nie uchyla wyroku skazującego, nie stanowi też odpowiednika orzeczenia uniewinniającego ani nie przywraca całkowicie stanu istniejącego przed skazaniem. W pewnych sytuacjach fakt wcześniejszego popełnienia przestępstwa może być uwzględniany. Nie popełnia przestępstwa osoba, która podnosi publicznie swój zarzut względem osoby pełniącej funkcję publiczną pod warunkiem, że jest on prawdziwy oraz służy ochronie społecznie uzasadnionego interesu. Natomiast podanie wybiórczej informacji o skazaniu osoby publicznej bez jednoczesnej informacji o zatarciu skazania przeczy zasadom dziennikarskiej rzetelności i może stanowić podstawę do odpowiedzialności cywilnej z tytułu naruszenia dóbr osobistych.
\end{abstract}

Słowa kluczowe: dobra osobiste, Kodeks cywilny, Kodeks karny, prawo prasowe, zniesławienie

Legal responsibility of a journalist for publishing information about the criminal record of a public person despite the expungement of the record: In the opinion of the author, expungement of a criminal record neither repels the conviction, nor it constitutes an equivalent of an acquittal, or it completely restores the state existing before the conviction. Despite this fact, in some situations the fact of having previously committed a crime may be taken into account. A person who publicly raises his objection against a person discharging a public function does not commit a crime provided that is the objection is true and serves to protect a socially justified interest. On the other hand, providing selective information about a conviction of a public person without simultaneous information about the expungement contradicts the principles of journalistic integrity and form a basis for a civil liability for infringement of personal rights.

Keywords: personal rights, Civil Code, Criminal Code, Press law, defamation

Radca prawny, ekspert ds. legislacji BAS - joanna.karolczak@sejm.gov.pl • https://orcid.org/0000-0002-5421-4683

\section{Przedmiot opinii}

Przedmiotem opinii jest odpowiedź na następujące pytanie: „jeżeli dziennikarz podaje do publicznej wiadomości informacje o karalności osoby publicznej, mimo faktu zatarcia tej karalności jeszcze przed datą publikacji, to czy narusza prawo, a jeśli tak to $\mathrm{w}$ jakim zakresie?”.

1 Opinia prawna dotycząca możliwości pociągnięcia do odpowiedzialności dziennikarza za opublikowanie informacji o karalności osoby publicznej pomimo faktu zatarcia tej karalności sporządzona 29 sierpnia 2019 r. na zlecenie posła Koła Poselskiego Wolni i Solidarni; BAS-WAP 1780/19. 
W opinii uwzględniono stan prawny na 29 sierpnia 2019 r. następujących aktów:

- ustawa z 6 czerwca 1997 r. - Kodeks karny, t.j. Dz.U. 2018, poz. 1600, ze zm.; dalej: k.k.,

- ustawa z 6 czerwca 1997 r. - Kodeks postępowania karnego, t.j. Dz.U. 2018, poz. 1987, ze zm.; dalej: k.p.k.,

- ustawa z 23 kwietnia 1964 r. - Kodeks cywilny, t.j. Dz.U. 2019, poz. 1145, ze zm.; dalej: k.c.,

- ustawa z 17 listopada 1964 r. - Kodeks postępowania cywilnego, t.j. Dz.U. 2019, poz. 1460, ze zm.; dalej: k.p.c.,

- ustawa z 26 stycznia 1984 r. - Prawo prasowe, t.j. Dz.U. 2018, poz. 1914,

- ustawa z 24 maja 2000 r. o Krajowym Rejestrze Karnym, t.j. Dz.U. 2019. poz. 1158.

\section{Uzasadnienie prawne}

Zatarcie skazania jest odrębną instytucją prawa karnego uregulowaną w rozdziale XII k.k. Istota zatarcia skazania polega na uznaniu, że po upływie określonego czasu (verba legis: „z chwilą zatarcia skazania”) skazanie uważa się za niebyłe, z czym wiąże się usunięcie odpowiedniego wpisu z rejestru skazanych (art. 106 k.k.). W obowiązującym stanie prawnym chodzi o usunięcie wpisu w rejestrze prowadzonym na podstawie ustawy o Krajowym Rejestrze Karnym, zgodnie $\mathrm{z}$ treścią art. 14 tej ustawy.

W doktrynie prawa i orzecznictwie podkreśla się, że instytucja ta eksponuje pierwiastek humanitarny, albowiem to właśnie względy humanitarne nakazują, by nie wypominać skazanemu w nieskończoność popełnienia przestępstwa i by piętno skazania i ukarania nie obciążało go przez całe życie. Długofalowym celem zatarcia skazania jest zatem ułatwienie integracji społecznej skazanego oraz umożliwienie mu powrotu do normalnego życia ${ }^{2}$.

Poglądy, dotyczące skutków zatarcia skazania i ich wpływu na dopuszczalność upublicznienia faktu popełnienia przestępstwa, za które skazanie uległo zatarciu, są w orzecznictwie i piśmiennictwie niejednolite.

W orzecznictwie sądów karnych podkreśla się, że zatarcie skazania jest pewną fikcją prawną i oznacza, że skazanemu ponownie przysługuje status osoby niekaranej, co wynika z przyjęcia, że skazanie jako zdarzenie historyczne nie miało w ogóle miejsca ${ }^{3}$. Zdaniem niektórych sądów skutek zatarcia skazania to nie

2 Postanowienie SN z 28 października 2009 r., sygn. akt I KZP 24/09, LEX nr 522882, oraz przywołane tam piśmiennictwo.

3 Tak np. SN w postanowieniu z 4 stycznia 2011 r., sygn. akt SDI 32/10, LEX nr 729694, oraz w wyroku z 20 maja 2015 r.; sygn. akt II KK 365/13, LEX nr 1466580; oraz Na- 
tylko uznanie za niebyłe skazania, ale i popełnienia przestępstwa ${ }^{4}$. Ten rezultat następuje z chwilą zatarcia i ukierunkowany jest na przyszłość, co oznacza, że od tego momentu fakt skazania nie może rodzić dla skazanego żadnych negatywnych konsekwencji, ponieważ przywrócony mu został status osoby niekaranej ${ }^{5}$. W niektórych judykatach sądów karnych przyjmuje się więc fikcję prawną, że do popełnienia przestępstwa w ogóle nie doszło ${ }^{6}$.

Pogląd ten jest jednak krytykowany w doktrynie prawa, gdzie podkreśla się, że art. 106 k.k. expressis verbis stanowi, że zatarcie skazania powoduje uznanie skazania za niebyłe. Wykładnia językowa tego przepisu nie pozostawia watpliwości, że obejmuje ono wyłącznie samo skazanie. Objęcie zatarciem skazania nie tylko samego faktu skazania, a także przestępstwa, którego dotyczy skazanie, wykraczałoby poza znaczenie językowe zwrotu „skazanie uważa się za niebyte” oraz pozostawałoby w sprzeczności z istota tej instytucji . Również Sąd Najwyższy zauważa, że z treści tego przepisu nie sposób zinterpretować normy prawnej, która pozwalałaby na stwierdzenie, że przywrócenie stanu niekaralności jest efektem „uchylenia” skazania i wywołanych nim skutków, a więc przywrócenia - w odniesieniu do skazanego - stanu sprzed skazania. Do takiego stanu prowadziłoby uchylenie takiego skazania w trybie kasacji (art. 529 k.p.k.) lub wznowienia postępowania (art. $545 \$ 1$ k.p.k. w związku z art. 529 k.p.k.) i umorzenie postępowania lub uniewinnienie skazanego, przy braku podstaw do stosowania środków zabezpieczających (art. 99 k.k.). Wówczas nastąpiłoby anulowanie konsekwencji wynikających ze skazania, a więc uchylenie ex tunc orzeczonej kary i środków karnych oraz przywrócenie stanu prawnego sprzed skazania ${ }^{8}$.

Jak zauważył Sąd Najwyższy, przyjęcie owej fikcji prawnej nie oznacza, iż $z a$ tarcie skazania stwarza niewzruszalne prawne domniemanie niewinności $w$ stosunku do danego czynu. Nie chodzi tu bowiem o domniemanie, lecz o fikcje prawna. Trudno mówić o domniemaniu, skoro zostało ono już wcześniej obalone prawomocnym wyrokiem [...]. Zatarcie skazania nie oznacza więc anulowania treści wyroku, tj. wyeliminowania go z moca wsteczna z porządku prawnego jako w ogóle niewydanego i nie niweluje też całkowicie wszystkich skutków skazania, bowiem

czelny Sąd Administracyjny w wyroku z 11 kwietnia 2014 r.; sygn. akt II GSK 279/13, LEX nr 1485533.

4 Wyroki SN z: 18 czerwca 2009, sygn. akt IV KK 164/09, LEX nr 512114; 10 listopada 2010 r., sygn. akt IV KK 326/10, LEX nr 653743.

5 Postanowienie SN z 21 sierpnia 2012 r., sygn. akt IV KK 59/12, LEX nr 126106.

6 Wyroki SN z: 29 sierpnia 2013 r., sygn. akt IV KK 168/13, LEX nr 1403563; 19 stycznia 2016 r., sygn. akt V KK 372/15, LEX nr 1958510.

7 B.J. Stefańska, Glosa do wyroku SN z dnia 29 sierpnia 2013 r., IV KK 168/13, „Przegląd Sądowy" 2014, nr 6, s. 138; zob. także eadem, Ujawnienie zatartego skazania a przestępstwo zniesławienia [w:] Przestępstwa przeciwko czci i nietykalności cielesne, red. M. Mozgawa, 2013, LEX.

8 Postanowienie SN z 28 października 2009 r., sygn. akt I KZP 24/09. 
skazany nie odzyskuje wszystkich utraconych np. praw, orderów czy odznaczeńn ${ }^{9}$. Skazanie jest bowiem uważane za niebyłe, ale dopiero z chwila jego zatarcia, od tego momentu dopiero funkcjonuje fikcja prawna i od tej też chwili nie może wywoływać żadnych negatywnych skutków prawnych dla skazanego. Podkreślić jednak należy, że wcześniej skazanie to istniało i wywoływało określone skutki wynikające $z$ treści wyroku ${ }^{10}$. Tak więc nie można uznać, że zatarcie skazania uchyla wyrok skazujący; nie stanowi też odpowiednika orzeczenia uniewinniającego, ani nie przywraca całkowicie stanu istniejącego przed skazaniem. Nie można, zdaniem sądów, zaakceptować stanowiska, że z chwilą zatarcia skazania należy przyjąć, że nastąpiło zatarcie faktu popełnienia przestępstwa i faktu skazania wskutek określonego wyroku ${ }^{11}$. Jak stwierdzono w orzecznictwie, zatarcie skazania nie wyłącza zastosowania art. 11 k.p.c. Ma ono wprawdzie ten skutek, że przestępstwo uważa się za niebyłe, ale taki skutek ogranicza się tylko do następstw karnych. Brak bowiem przepisu, który by przewidywał, że po zatarciu skazania wyrok karny traci moc orzeczenia wiążacego sąd cywilny ${ }^{12}$. Nawet w postępowaniu karnym, w którym zatarcie pociąga za sobą w zasadzie bezwzględnie przestrzegane konsekwencje, przyjmuje się, że w pewnych wypadkach fakt zatartego skazania należy brać pod uwagę . $^{13}$.

Warto także zauważyć, że orzecznictwo z zakresu prawa ubezpieczeniowego i orzecznictwo administracyjne skłaniają się do dopuszczalności uwzględnienia informacji o zatarciu skazania w przypadku, gdy fakt popełnienia przestępstwa stanowił zdarzenie wpływające na uprawnienie do świadczeń, nawet jeśli w chwili wydawania deklaratoryjnej decyzji w tej materii skazanie uległo już za-

9 Zatarcie skazania dotyczace pracownika służby cywilnej nie ma wplywu na możliwość przywrócenia go do pracy, jeśli umowa o pracę została rozwiązana właśnie z powodu skazania za przestępstwo umyślne - wyrok SN z 10 lutego 2005 r., sygn. akt II PK 247/04, LEX nr 603765; Oficer zawodowy, skazany prawomocnym wyrokiem na kare pozbawienia wolności i zwolniony dyscyplinarnie z tego powodu ze służby, nie odzyskuje przez zatarcie skazania prawa do petnej emerytury wojskowej - wyrok Trybunału Ubezpieczeń Społecznych 19 lutego 1974 r., sygn. akt IV TR 1795/73, niepubl., cyt. za. B.J. Stefańska, Ujawnienie, op. cit.

10 Wyrok SN z 4 stycznia 2011 r., sygn. akt SDI 32/10, i przywołana tam literatura oraz orzecznictwo.

11 Naczelny Sąd Administracyjny w wyroku z 11 kwietnia 2014 r.; sygn. akt II GSK 279/13.

12 Zgodnie $\mathrm{z}$ art. 11 k.p.c., ustalenia wydanego w postępowaniu karnym prawomocnego wyroku skazującego co do popetnienia przestępstwa wiąża sąd w postępowaniu cywilnym. Jednakże osoba, która nie była oskarżona, może powoływać się w postępowaniu cywilnym na wszelkie okoliczności wyłączające lub ograniczające jej odpowiedzialność cywilną. Postanowienie SN z 24 lutego 2005 r., sygn. akt III UK 6/05, Legalis nr 216704, wyrok Sądu Apelacyjnego w Warszawie z 12 grudnia 2018 r., sygn. akt V ACa 1519/17, LEX nr 2610116.

13 Postanowienie SN z 28 października 2009 r., sygn. akt I KZP 24/09. 
tarciu ${ }^{14}$. Podobnie oceniane są przypadki, w których ocenie podlegają kwalifikacje społeczno-moralne danej osoby niezbędne do uzyskania określonych przywilejów, świadczeń, zezwoleń lub objęcia stanowiska wymagającego spełniania podwyższonych, szczególnych warunków osobistych ${ }^{15}$. Podkreśla się jednak, że nie tyle chodzi wówczas o fakt skazania, ile o sygnał wskazujący na dotychczasowe życie osoby poddanej ocenie. Mimo więc, że w wyniku zatarcia skazania osoba skazana może się przedstawiać jako niekarana i jako taka powinna być traktowana, w pewnych sytuacjach fakt wcześniejszego popełnienia przestępstwa może, a nawet powinien być uwzględniany, może więc być też ustalany i ujawniany w ramach realizacji konstytucyjnego prawa do informacji. Nie oznacza to jednak swobody ani dowolności w publikowaniu takiej informacji.

Zdaniem Sądu Najwyższego: w pewnych wypadkach informacja o popetnieniu w przeszłości przestępstwa może mieć znaczenie przy dokonywaniu oceny kwalifikacji moralnych, gwarancji prawidłowego działania czy określonych predyspozycji. Taka potrzeba musi być jednak traktowana jako wyjątkowa, powstajaca w szczególnych okolicznościach i związana z koniecznością ochrony szczególnie cennych wartości. Ujawnienie takiego faktu z zasady nie powinno następować publicznie, nawet jeśli chodzi o osoby petniace publiczne funkcje, niemniej nie jest wyłaczona dopuszczalność ujawnienia takiego faktu także publicznie, jeśli wymaga tego interes społeczny. Niezbędne jest jednak każdorazowo wyważenie prawa do swobody wypowiedzi i informacji oraz prawa do ochrony dobrego imienia $w$ drodze korzystania $z$ dobrodziejstwa zatarcia skazania. Ocena powinna zmierzać do ustalenia, czy i jakie wnioski o cechach $i$ właściwościach osoby skazanej w przeszłości pozwala wysnuć wiedza o popetnieniu przez nia przestępstwa. Znaczenie może $w$ tym

14 Postanowienie SN z 24 czerwca 2015 r., sygn. akt IV UK 247/14, LEX nr 1764809.

15 Uchwała SN z 27 listopada 1984 r., sygn. akt III AZP 6/84, LEX nr 9485: Okoliczność, że skazanie za określone przestępstwo uległo zatarciu (art. 110 i nast. k.k.), nie wyłacza możliwości oceny zachowania się osoby, w stosunku do której zatarcie nastapiło, celem ustalenia, czy spetnia ona warunki $z$ ustawy z dnia 26 maja 1982 r. o szczególnych uprawnieniach kombatantów (Dz.U. Nr 16, poz. 122) do uzyskania świadczeń $w$ tej ustawie przewidzianych, oraz wyroki Wojewódzkiego Sądu Administracyjnego w Warszawie z: 6 lipca 2005 r., sygn. akt VI SA/Wa 2263/04, LEX nr 183633; 20 lipca 2007 r., sygn. akt VI SA/Wa 820/07, LEX nr 372103; 17 lipca 2008 r., sygn. akt VI SA/Wa 669/08, LEX nr 491336. Minister Sprawiedliwości badając czy kandydat spetnia przesłanke $z$ art. 65 pkt 1 ustawy z 1982 r. Prawo o adwokaturze, czyli czy jest nieskazitelnego charakteru i swym dotychczasowym postępowaniem daje rękojmię należytego wykonywania zawodu adwokata, powinien brać pod uwage wszystkie okoliczności składające się na wizerunek kandydata, a więc także znane mu zdarzenia, które legły u podstaw wydania wyroku skazujacego, mimo iż skazanie uległo zatarciu. Zachowania te, jako fakty społeczne nadal istnieja i moga być brane pod uwage przy ocenie sylwetki kandydata, wyrok Naczelnego Sądu Administracyjnego z 16 marca 2018 r., sygn. akt II GSK 1686/16, LEX nr 2495416. 
wypadku mieć kiedy doszło do popetnienia przestępstwa, skazania i jego zatarcia, późniejsze postępowanie tej osoby $i$ wszelkie elementy wpływające na obraz jej osobowości. Ujawnienie zatartego skazania nie może w żadnym razie służyć stworzeniu sensacyjnej wiadomości, lecz wyłacznie zapewnieniu niezbędnej społeczeństwu informacji o rzeczywistym zagrożeniu ważnych wartości z powodu uzasadnionych obaw, że popetnione kiedyś przez tę osobę przestępstwo dowodzi takich jej właściwości, które powodują, że nie daje ona rękojmi właściwej realizacji wykonywanych zadań, ze względu na ich specyfikę, charakter, zakres uprawnień lub wątpliwą skuteczność sprawowanej nad nią kontroli ${ }^{16}$. W konsekwencji dopuszczalne jest przełamanie fikcji niekaralności $w$ przypadku zatarcia skazania i ujawnienie informacji o tymże skazaniu, gdy przemawia za tym interes społeczny, znajdujacy odbicie $w$ konkretnych okolicznościach sprawy ${ }^{17}$.

W wyroku z 31 marca 2016 r., sygn. akt VI ACa 1275/14, Sąd Apelacyjny w Warszawie wskazał, że np. w przypadku powołania na wysokie stanowisko $\mathrm{w}$ jednym $\mathrm{z}$ ministerstw, która to funkcja wiązała się $\mathrm{z}$ decydowaniem o środkach publicznych, społeczeństwo miało prawo do informacji o zatrudnieniu na tak eksponowanym stanowisku osoby, której właściwości i warunki osobiste nie korespondują z wymaganiami stawianymi takiej funkcji i która go piastować nie powinna. Dlatego też podanie informacji o jej skazaniu za umyślne przestępstwo przeciwko mieniu w artykułach prasowych pozostawało w tej konkretnej sytuacji w interesie społecznym, publicznym. W związku z tym, mimo że doszło niewątpliwie do naruszenia czci, jak też prywatności powoda, pozwani przeprowadzili skuteczną egzonerację w rozumieniu art. $24 \$ 1$ k.c., wykazując, oprócz prawdziwości wspomnianej informacji, istnienie interesu społecznego w jej ujawnieniu.

Za dominujące w judykaturze Europejskiego Trybunału Praw Człowieka uznać można przekonanie, zgodnie z którym osoby prowadzące działalność publiczną, w szczególności uczestniczące w sporach politycznych, w sposób nieunikniony, a zarazem świadomy i dobrowolny, wystawiają się na kontrolę i reakcję ze strony opinii publicznej i muszą wykazać większy stopień tolerancji nawet wobec szczególnie brutalnych ataków skierowanych przeciwko nim. Tego

16 Wyrok SN z 29 października 2015 r., sygn. akt I CSK 893/14, LEX nr 1991135; wyrok Sądu Apelacyjnego w Warszawie z 31 marca 2016 r., sygn. akt VI ACA 1275/14, LEX nr 2075678.

17 Uchwała SN z 27 listopada 1984 r., sygn. akt III AZP 6/84; a także wyroki WSA w Warszawie z: 6 lipca 2005 r., sygn. akt VI SA/Wa 2263/04; 17 lipca 2008 r., sygn. akt VI SA/ Wa 669/08: Zatarcie skazania nie stanowi przeszkody do dokonywania ustaleń $w$ trybie art. 75 k.p.a., że dana osoba, będąc biegłym popetnita czyn naganny, który sam w sobie lub w powiązaniu z innymi okolicznościami może podważać jej wiarygodność oraz rękojmię w rozumieniu przepisów rozporządzenia Ministra Sprawiedliwości w sprawie biegłych sądowych. Zatarcie skazania pozwala wprawdzie dana osobę uznać za niekarana, jednakże przy ocenie rękojmi ważny jest nie tyle fakt ukarania bądź nieukarania, ale dotychczasowe życie i sposób postępowania tej osoby. 
wymaga w szczególności prawo do otwartej i nieskrępowanej debaty publicznej, stanowiącej jedną z podstawowych wartości państwa demokratycznego. Z tego względu w każdym przypadku zakres przyznanej ochrony prawnej winien być wyznaczony $z$ uwzględnieniem tych okoliczności ${ }^{18}$. Powołując się na skazanie, które uległo zatarciu, dostarcza się społeczeństwu informację, której było ono wcześniej pozbawione. W demokratycznym społeczeństwie powinna istnieć możliwość powołania się na przestępstwa i wykroczenia popełnione w przeszłości przez polityka, nawet jeśli doszło już do odbycia kary, wyrok został zawieszony lub uległ zatarciu. Skazanie w przeszłości polityka może być bowiem istotną wiadomością, potrzebną do oceny, czy jest on właściwą osobą, by pełnić funkcje publiczne. $\mathrm{Z}$ jednej strony opinia publiczna ma zatem prawo do informacji o przeszłości osób, które ją reprezentują; z drugiej - polityk musi tolerować, że fakty z jego życia są sprawdzane, nawet gdy sam nie był uczestnikiem politycznej kontrowersji. Wynika stąd, że nawet w sytuacji zatarcia skazania opinia publiczna ma prawo wiedzieć o takiej jego przeszłości ${ }^{19}$. W efekcie granice krytyki w odniesieniu do tej kategorii osób i wypowiedzi są zdecydowanie szersze ${ }^{20}$. Zdaniem P. Kosmatego: $w$ przypadku polityka należy przyznać pierwszeństwo wolności słowa przed dobrodziejstwem wypływajacym z instytucji zatarcia skazania a politycy musza liczyć się z tym, że pomimo zatarcia skazania informacja o złamaniu $w$ przeszłości przez nich prawa przedostanie się do opinii publicznej ${ }^{21}$. Zdaniem J. Sobczaka: stanowisko ETPC wydaje się wysoce kontrowersyjne. Instytucja prawa karnego - jaka jest zatarcie skazania - ma określone cele, nie tylko o charakterze resocjalizacyjnym. Ma umożliwić powrót człowieka kiedyś skazanego i prawidłowe funkcjonowanie takiej osoby w różnych dziedzinach życia. Wypominanie politykowi po wielu latach błędów popełnionych $w$ młodości, skazania np. na przestępstwo nieumyślne lub niekryminalne, na kare dawno odbyta i zatarta - nie znajduje żadnego uzasadnienia. Funkcji usprawiedliwiajacej ujawnianie takich informacji nie może pełnić hasło transparentności ani dążenie do weryzmu. Ujawnianie takich informacji zdaje się przeczyć postulatowi równości wobec prawa. Jako szczegól-

18 Tak m.in. orzeczenie ETPC z 8 lipca 1986 r. w sprawie Lingens vs. Austria; orzeczenie z 23 maja 1991 r. w sprawie Oberschlick vs. Austria (I); orzeczenie z 23 kwietnia 1992 r. w sprawie Castells vs. Hiszpania; orzeczenie z 28 sierpnia 1992 r. w sprawie Schwabe vs. Austria; orzeczenie z 21 stycznia 1999 r. w sprawie Janowski vs. Polska; orzeczenie z 27 lutego 2001 r. w sprawie Jerusalem vs. Austria; orzeczenie z 29 marca 2005 r. w sprawie Ukraińska Grupa Prasowa vs. Ukraina; orzeczenie z 29 marca 2005 r. w sprawie Sokołowski vs. Polska.

19 Wyrok ETPC z 28 sierpnia 1992 r., Schwabe v. Austria, skarga nr 13704/88, A. 242-B, s. $1037-1039$.

20 J. Szczechowicz, Prawne aspekty ochrony dóbr osobistych, http://uwm.edu.pl/mk.k.s/ wp-content/uploads/12-szczechowicz.pdf [dostęp 26 sierpnia 2019 r.].

${ }^{21}$ P. Kosmaty, Zatarcie skazania a wolność wypowiedzi, www.rp.pl/Sady-i-prokuratura/3122499984-Piotr-Kosmaty [dostęp 26 sierpnia 2019 r.]. 
nie niebezpieczne uznać należy pojawiające się $w$ literaturze głosy, iż treść wspomnianych orzeczeń pozwala na wskazanie osób, co do których konkretni sędziowie orzekli zatarcie skazania albo głowa państwa skorzystała z prawa łaski. Tego typu działania - tak dziennikarzy, jak polityków - godza wprost w zasadę resocjalizacji i humanitaryzmu. Nie sposób także uznać, że wspomniane orzeczenie pozwala na ujawnienie, że osoby np. nagrodzone odznaczeniami były w przeszłości skazane za przestępstwa, a odbyta kara została zatarta ${ }^{22}$.

W kontekście tych rozważań - zdaniem B.J. Stefańskiej - nasuwają się pytania, czy wyczerpuje znamiona pomówienia z art. $212 \$ 1$ lub 2 k.k. ujawnienie karalności, która uległa zatarciu lub podanie do wiadomości faktu zatarcia skazania oraz czy - co się z tym wiąże - dopuszczalne jest przeprowadzenie dowodu prawdy (art. $213 \$ 1$ i 2 k.k.) ${ }^{23}$. Na pierwsze pytanie - w opinii przywołanej autorki - należy udzielić odpowiedzi pozytywnej, a na drugie - negatywnej24. W literaturze przyjmuje się, że rozgłoszenie faktu skazania, które uległo zatarciu, może stanowić przestępstwo z art. $212 \$ 1$ lub 2 k.k. ${ }^{25}$. Podkreśla się, że zatajenie faktu zatarcia skazania sprowadza się do głoszenia faktu nieprawdziwego ${ }^{26}$. Skoro zatarcie skazania powoduje uznanie skazania za niebyłe, to nie można $z$ tego powodu nikomu czynić zarzutu. Z zatartego skazania nie można wyciągać żadnych skutków prawnych, jakie prawo wiąże z karalnością zarówno w sferze prawa karnego, jak i innych dziedzin życia ${ }^{27}$. Prima facie wydawać by się mogło, że rozgłoszenie faktu zatarcia nie stanowi przestępstwa, gdyż zatarcie skazania jest faktem pozytywnym, wywołującym korzystne następstwa dla skazanego, a więc nie jest właściwością, która mogłaby poniżyć daną osobę w opinii publicznej lub narazić na utratę zaufania potrzebnego dla danego stanowiska, zawodu lub rodzaju działalności. W istocie jednak podanie tego faktu do wiadomości jest informacja także o skazaniu. Podanie informacji o zatarciu skazania stanowiłoby niedopuszczalne obejście ustawy i unicestwiałoby instytucję zatarcia skazania, które przecież upoważnia do twierdzenia o braku karalności ${ }^{28}$.

W doktrynie nie ma zgodności poglądów co do dopuszczalności w takiej sytuacji dowodu prawdy. Zauważa się, że podnoszenie publicznie faktu, że dana osoba była skazana, może leżeć w uzasadnionym interesie społecznym oraz że

22 J. Sobczak, Prawo prasowe. Komentarz, 2008, LEX, komentarz do art. 1.

23 B.J. Stefańska, Ujawnienie, op. cit.

24 Eadem, Skutki zatarcia skazania, https://pk.gov.pl/wp-content/uploads/2013/12/ b26ffd0ce2b5b470aa577a03409f7884.doc [dostęp 26 sierpnia 2019 r.].

25 M. Piekarski, Ochrona czci osób zrehabilitowanych, „Państwo i Prawo” 1948, nr 11, s. 93-94; L. Wilk, [w:] Kodeks karny. Komentarz, t. 1, red. W. Wróbel, A. Zoll, Warszawa 2004, s. 1329.

26 M. Piekarski, Ochrona, op. cit., s. 94.

27 J. Wojciechowski, Kodeks karny z krótkim komentarzem praktycznym, Skierniewice 1992, s. 133.

28 W. Wolter, Zarys systemu prawa karnego. Część ogólna, t. II, Kraków 1993, s. 164-165. 
pierwszeństwo należy dać interesowi publicznemu lub prywatnemu, uzasadniającemu podniesienie takiego twierdzenia ${ }^{29}$. Wprawdzie zakwestionowano konieczność dania pierwszeństwa interesowi prywatnemu oskarżonego, sąd bowiem nie jest powołany do ochrony interesów prywatnych, lecz do ochrony publicznego ładu prawnego, ale dopuszczanie dowodu prawdy uzasadnia się treścią art. 213 k.k. ${ }^{30}$. Uznaje się też, że oskarżony nie może udowadniać prawdziwości zarzutu, dowód skazania nie wyklucza przestępstwa ${ }^{31}$. Podkreśla się, że: zatarcie skazania powoduje, że skazanie uważa się za niebyłe, wobec tego zarzut musi uchodzić za nieprawdziwy, co znaczy, że pomawiający dopuściłby się przestępstwa $a^{32}$. Prezentowane też jest stanowisko pośrednie. Według niego szerokie stosowanie w takiej sytuacji dowodu prawdy byłoby niezgodne $\mathrm{z}$ wyjątkowością tej instytucji, toteż dopuszcza się taki dowód w wypadku zniesławienia, a neguje w razie znieważenia (art. $216 \$ 1$ k.k.). Karalność za zniesławienie wchodzi w grę $\mathrm{w}$ razie rozgłoszenia prawdziwej informacji o zatarciu skazania, jeżeli było zamierzone pomówienie o postępowanie lub właściwości mogące poniżyć w opinii publicznej lub narazić na utratę zaufania, np. przez podanie, że osoba, której zatarto skazanie, dla zysku nie zawaha się powrócić na drogę przestępstwa ${ }^{33}$. Zdaniem B.J. Stefańskiej większe uzasadnienie aksjologiczne w zatarciu skazania ma koncepcja odrzucająca przeprowadzenie dowodu prawdy ${ }^{34}$.

Jak twierdzi M. Błaszczyk, zatarcie skazania jest instytucją znoszącą wszelkie prawne skutki skazania i wiążącą podmioty sprawujące funkcje publiczne, o ile stosowanie tej instytucji nie koliduje ze sferą interesu publicznego, z interesem prywatnym innej osoby lub też z interesem samego skazanego. W niektórych przypadkach takich kolizji dóbr należy się opowiedzieć za dopuszczalnością wyjątku od art. 106 k.k. Sztywne trzymanie się obowiązywania fikcji niekaralności mogłoby bowiem prowadzić do sytuacji niemożliwych do zaakceptowania czy wręcz absurdalnych. Co do kolizji sfery interesu prywatnego - tu interesu byłego skazanego - ze sferą interesu publicznego zastosowanie wyjątku w stosunku do art. 106 k.k. powinno zostać poprzedzone wnikliwą analizą racji przemawiających na rzecz tego wyjątku, celowościowo zorientowanym bilansem zysków i strat. Podobnie należałoby ocenić przypadek kolizji interesu byłego skazanego z interesem prywatnym innej osoby. Zasada, że po zatarciu skazania fakt skazania jako - w świetle prawa - niebyły, nie może rodzić dla byłego skazanego żadnych skutków, doznawać musi pewnych oczywistych wyjątków. Zatarcie ska-

29 L. Gardocki, Prawo karne, Warszawa 2004, s. 204.

30 M. Piekarski, Ochrona, op. cit., s. 94-95; Z. Papierkowski, Rehabilitacja, zatarcie skazania a zniesławienie, „Głos Sądownictwa” 1934, s. 564-565.

31 M. Piekarski, Ochrona, op. cit., s. 94.

32 W. Wolter, Zarys, op. cit., s. 165.

33 M. Piekarski, Ochrona, op. cit., s. 96.

34 B.J. Stefańska, Skutki zatarcia skazania, op. cit. 
zania bezpośrednio skutkuje jedynie w sferze prawnej ${ }^{35}$. Jednak w sytuacji, kiedy informacja o fakcie skazania, które uległo już zatarciu, jest podnoszona publicznie - czyli może dotrzeć do nieoznaczonego kręgu odbiorców (np. czytelników prasy, słuchaczy radia, uczestników spotkania wyborczego) albo do oznaczonej, większej liczby osób (np. zgromadzonych na zebraniu wspólnoty mieszkaniowej bloku) - podający ją nie popełnia przestępstwa zniesławienia, jeżeli publicznie podnosi lub rozgłasza prawdziwy zarzut służacy obronie społecznie uzasadnionego interesu (art. $213 \$ 2$ k.k.). Kontratypem będzie więc objęte publiczne podanie informacji prawdziwej - o skazaniu, które miało miejsce, chociaż uległo zatarciu - w społecznie uzasadnionym interesie. De lege lata wymóg kumulatywnej realizacji obu przesłanek kontratypu wprowadzonego przez przepis art. $213 \$ 2$ k.k. nie odnosi się do osób pełniących funkcje publiczne. Regulacja tego kontratypu uległa bowiem zmianie 8 czerwca 2010 r. w związku z wejściem w życie nowelizacji Kodeksu karnego (ustawy z 5 listopada 2009 r., Dz.U. nr 206, poz. 1589, ze zm.), która m.in. dostosowała art. $213 \$ 2$ k.k. do standardów konstytucyjnych. Zdaniem Trybunału Konstytucyjnego art. $213 \$ 2$ k.k. w brzmieniu sprzed tej nowelizacji był niezgodny z wymogami Konstytucji RP w części obejmującej zwrot „służący obronie społecznie uzasadnionego interesu”, gdy zarzut dotyczył postępowania osób pełniących funkcje publiczne ${ }^{36}$. W uzasadnieniu wyroku wskazano, że: podnoszenie lub rozgłaszanie prawdziwych zarzutów dotyczacych osób pełniących funkcje publiczne o takie postępowanie lub właściwości, które moga narazić je na utratę zaufania potrzebnego dla danego stanowiska, zawodu lub rodzaju działalności (co znaczy, że w rzeczywistości podmiot ten na zaufanie potrzebne dla aktywności $w$ sferze publicznej nie zasługuje) jest czynem - niezależnie od intencji sprawcy - ex definitione służacym społecznie uzasadnionemu interesowi co stanowi odrębnie sformułowane $w$ art. $213 \$ 2$ k. k. znamię kontratypu ${ }^{37}$.

Przypomnieć także należy, w kontekście sformułowanego we wstępie do opinii pytania dotyczącego dziennikarza, że zgodnie z prawem prasowym prasa korzysta z wolności wypowiedzi i urzeczywistnia prawo obywateli do ich rzetelnego informowania, jawności życia publicznego oraz kontroli i krytyki społecznej. Na wątpliwości związane z uprawnieniami dziennikarzy zwraca uwagę E. Nowińska: Zatarcie oznacza bowiem, że $w$ świetle przepisów prawa osoba niegdyś skazana nie jest już uważana za karana. W związu z tym, jeśli media opisuja bardziej lub mniej interesujaca historię czyjegoś życia i przypominaja, że był karany np. 15 lat temu za określone przestępstwo, powinni zweryfikować, czy nie doszło do zatarcia skazania. Po upływie okresu zatarcia, który jest różny dla poszczególnych typów przestępstw, skazany ma prawo twierdzić, że nie byt karany. W związu z tym

35 M. Błaszczyk [w:] Kodeks karny. Część ogólna. Komentarz. Art. 1-116, red. M. Królikowski, R. Zawłocki, Warszawa 2017, cyt. za Legalis.

36 Za: ibidem.

37 Wyrok TK z 12 maja 2008 r., sygn. akt SK 43/05, OTK-A ZU 2008, nr 4, poz. 57. 
powstaje pytanie, czy istnieja sytuacje, w których można poinformować o takiej okoliczności życia określonej osoby. Odpowiedź jest niezwykle trudna z prawnego punktu widzenia, bowiem formalne zatarcie skazania „wymazuje” z pamięci społecznej ten fakt. $Z$ drugiej jednak strony można przytoczyć szereg argumentów przemawiajacych za tym, aby informację taka jednak przekazać, kierując się względami interesu społecznego, który przecież jest brany pod uwagę $w$ zakresie oceny bezprawności dokonanego przez dziennikarzy naruszenia, w szczególności dóbr osobistych. Jeśli jednak zważyć, iż podstawa wprowadzenia tej instytucji były m.in. względy humanitarne, które pozwalaja nie ujawniać takiej niekorzystnej przeciez informacji, wywolujacej wiele negatywnych konsekwencji na dalszych etapach życia, odpowiedź powinna być negatywna ${ }^{38}$. Zdaniem cytowanej autorki, jeśli w przekazaniu takiej informacji zaangażowany jest istotny interes informacyjny społeczeństwa, to podanie do publicznej wiadomości takiej okoliczności jest dopuszczalne.

Jak wskazał Sąd Apelacyjny w Warszawie w wyroku z 31 marca 2016 r. (sygn. akt VI ACa 1275/14): w pewnych wypadkach informacja o popetnieniu $w$ przeszłości przestępstwa może mieć znaczenie przy dokonywaniu oceny kwalifikacji moralnych, gwarancji prawidłowego działania czy określonych predyspozycji. Jednak taka potrzeba traktowana być musi jako wyjatkowa, powstajaca w szczególnych okolicznościach i związana $z$ koniecznościa ochrony szczególnie cennych wartości. Ujawnienie takiego faktu $z$ reguty nie powinno następować publicznie, nawet jeśli chodzi o osoby petniace publiczne funkcje. Niemniej nie jest wyłączona dopuszczalność ujawnienia takiego faktu także publicznie, jeśli wymaga tego interes społeczny. Niezbędne będzie jednak każdorazowo wyważenie prawa do swobody wypowiedzi i informacji oraz prawa do ochrony dobrego imienia $w$ drodze korzystania $z$ dobrodziejstwa zatarcia skazania. Ocena powinna zmierzać do ustalenia, czy i jakie wnioski o cechach $i$ właściwościach osoby skazanej w przeszłości pozwala wysnuć wiedza o popełnieniu przez nia przestępstwa. Znaczenie może w tym wypadku mieć postępowanie tej osoby i wszelkie elementy wplywajace na obraz jej osobowości. Ujawnienie zatartego skazania nie może $w \dot{z} a d n y m$ razie służyć stworzeniu sensacyjnej wiadomości, lecz wyłacznie zapewnieniu niezbędnej społeczeństwu informacji o rzeczywistym zagrożeniu ważnych wartości z powodu uzasadnionych obaw, że popetnione kiedyś przez tę osobe przestępstwo dowodzi takich jej właściwości, które powodują, że nie daje ona rękojmi właściwej realizacji wykonywanych zadań, ze względu na ich specyfike, charakter, zakres uprawnień lub watpliwa skuteczność sprawowanej nad nią kontroli.

Zgodnie $\mathrm{z}$ art. 38 ust. 1 prawa prasowego odpowiedzialność cywilną za naruszenie prawa spowodowane opublikowaniem materiału prasowego ponoszą autor, redaktor lub inna osoba, którzy spowodowali opublikowanie tego materiału; nie wyłącza to odpowiedzialności wydawcy. W zakresie odpowiedzial-

38 E. Nowińska, Wolność wypowiedzi prasowej, 2007, LEX. 
ności majątkowej odpowiedzialność tych osób jest solidarna. Publikacja materiału prasowego może naruszać dobra osobiste osoby fizycznej lub prawnej, na przykład przez nieuzasadnioną krytykę, bezprawne ujawnianie informacji z życia prywatnego, ujawnianie informacji objętych tajemnicą prawnie chronioną, zniesławienie. Zasady odpowiedzialności cywilnej w przypadku naruszenia dóbr osobistych zawiera art. 23 k.c., zgodnie z którym dobra te pozostają pod ochroną prawa cywilnego, niezależnie od ochrony przewidzianej w innych przepisach.

Z przepisów prawa prasowego wynika obowiązek rzetelności dziennikarskiej. Stanowi o tym art. 1, według którego prasa, zgodnie z Konstytucją Rzeczypospolitej Polskiej, korzysta z wolności wypowiedzi i urzeczywistnia prawo obywateli do ich rzetelnego informowania, jawności życia publicznego oraz kontroli i krytyki społecznej, a także art. 12 ust. 1 pkt 1 i 2 tej ustawy, według którego dziennikarz jest obowiązany zachować szczególną staranność i rzetelność przy zbieraniu i wykorzystaniu materiałów prasowych, zwłaszcza sprawdzić zgodność z prawdą uzyskanych wiadomości lub podać ich źródło, oraz chronić dobra osobiste, a ponadto interesy działających w dobrej wierze informatorów i innych osób, które okazują mu zaufanie. Dodatkowo uściśla pojęcie rzetelności treść art. 6 ust. 1 prawa prasowego, zgodnie z którym prasa jest zobowiązana do prawdziwego przedstawiania omawianych zjawisk. Zatajenie, że nastąpiło już zatarcie skazania, prowadzi do fałszowania rzeczywistości. W przypadku zamieszczenia w prasie nieprawdziwej wiadomości o skazaniu danej osoby za przestępstwo mamy do czynienia $\mathrm{z}$ naruszeniem dóbr osobistych w postaci godności osobistej i dobrego imienia $^{39}$. Zgodnie $\mathrm{z}$ art. $24 \$ 1$ k.c. ten, czyje dobro osobiste zostaje zagrożone cudzym działaniem, może żądać zaniechania tego działania, chyba że nie jest ono bezprawne. W razie dokonanego naruszenia może on także żądać, aby osoba, która dopuściła się naruszenia, dopełniła czynności potrzebnych do usunięcia jego skutków, w szczególności by złożyła oświadczenie odpowiedniej treści i w odpowiedniej formie. Na zasadach przewidzianych w Kodeksie cywilnym może on również żądać zadośćuczynienia pieniężnego lub zapłaty odpowiedniej sumy pieniężnej na wskazany cel społeczny. Ponadto, zgodnie z treścią $₫ 2$ tego przepisu, jeżeli wskutek naruszenia dobra osobistego została wyrządzona szkoda majątkowa, poszkodowany może żądać jej naprawienia na zasadach ogólnych.

Warto wskazać, że za bezprawne uważa się każde działanie naruszające dobro osobiste, jeżeli nie zachodzi żadna ze szczególnych okoliczności usprawiedliwiających. Do okoliczności wyłączających bezprawność naruszenia dóbr osobistych często zalicza się: 1) działanie dozwolone przez obowiązujące przepisy prawa, 2) wykonywanie prawa podmiotowego, 3) zgode pokrzywdzonego (ale nie w każdym przypadku), 4) działanie w obronie uzasadnionego interesu ${ }^{40}$.

39 Wyrok Sądu Apelacyjnego w Poznaniu z 10 stycznia 2008 r., sygn. akt I ACa 1048/07, LEX nr 466432.

40 E. Ferenc-Szydełko, Prawo prasowe. Komentarz, 2013, LEX, komentarz do art. 38. 
W orzecznictwie przyjmuje się, że skuteczne powołanie się na wyłączenie bezprawności naruszenia dóbr osobistych z powodu działania w obronie społecznie uzasadnionego interesu wymaga wykazania co najmniej, że krytyka opiera się na informacjach, które zostały rzetelnie i starannie zebrane oraz zweryfikowane; tylko krytyka rzeczowa i rzetelna może rzeczywiście służyć dobru społeczne$\mathrm{mu}^{41}$. Działanie w obronie interesu społecznie uzasadnionego mogłoby wyłączać bezprawność tylko wówczas, gdyby jednocześnie dochowana została należyta staranność przy publikacji materiału, przy przyjęciu podwyższonego miernika należytej staranności wynikającego z zawodowego charakteru działalności dziennikarza. Tylko wtedy podanie nawet niekorzystnej informacji nie będzie działaniem bezprawnym ${ }^{42}$.

Należy przy tym zaznaczyć, że na podstawie art. $213 \$ 2$ k.k. w przypadku osób pełniących funkcje publiczne postawiony zarzut musi być zgodny z prawdą, ale naruszyciel nie musi działać w obronie społecznie uzasadnionego interesu.

Zachowanie szczególnej staranności i rzetelności w rozumieniu art. 12 ust. 1 pkt 1 prawa prasowego byłoby - zdaniem sądów - niewystarczające, gdyby nie nieodzowna dla wyłączenia bezprawności naruszenia dobra osobistego przesłanka działania w uzasadnionym interesie społecznym. Wprawdzie nie ma przepisu, który wprost wskazywałby na wyłączenie bezprawności wskutek działania w obronie uzasadnionego interesu społecznego, ale przesłanka ta, wyłączająca bezprawność naruszenia dóbr osobistych, konstruowana jest w orzecznictwie $^{43}$. Bezprawność zachowania sprawcy naruszenia dóbr osobistych polega na sprzeczności z szeroko rozumianym porządkiem prawnym, a zatem z normami prawnymi lub regułami postępowania wynikającymi z zasad współżycia społecznego. W wypadku publikacji prasowych interes ten wyraża się przede wszystkim w urzeczywistnianiu zasad jawności życia publicznego i prawa społeczeństwa do informacji. Jednakże za działanie w imię uzasadnionego interesu społecznego uznaje się także rozpowszechnianie w prasie prawdziwych informacji o pojedynczych faktach lub powtarzających się zdarzeniach, które dotykają lub mogą dotyczyć bliżej nieoznaczonej grupy ludzi względnie całego społeczeństwa i z punktu widzenia tej grupy lub całego społeczeństwa zasługują na poparcie lub krytykę ${ }^{44}$. Zatem wybiórcze podanie informacji jedynie o karalności danej osoby, bez jednoczesnego poinformowania opinii publicznej o zatarciu skazania nie spełnia kryterium rzetelności dziennikarskiej i może stanowić podstawę do dochodzenia roszczeń niemajątkowych. Jeżeli wskutek naruszenia dobra osobistego zosta-

41 Wyrok Sądu Apelacyjnego w Warszawie z 24 maja 2018 r., sygn. akt V ACa 256/17, LEX nr 2519462.

42 Wyrok Sądu Apelacyjnego w Warszawie z 21 maja 2018 r., sygn. akt I ACa 164/18, LEX nr 2516032.

43 Wyrok Sądu Apelacyjnego w Białymstoku z 27 kwietnia 2018 r., sygn. akt I ACa 22/18, Legalis 1814797.

44 Na przykład wyrok SN z 9 grudnia 2009 r., sygn. akt IV CSK 290/09, Legalis 309976. 
ła wyrządzona szkoda majątkowa, poszkodowany może żądać jej naprawienia na zasadach ogólnych, zgodnie z przepisami art. 361-363 k.c.

Należy jeszcze wspomnieć o tzw. prawie do bycia zapomnianym. W wyroku z 13 maja 2014 r. TSUE orzekł m.in., że art. 12 lit. b i art. 14 akapit pierwszy lit. a dyrektywy 95/46/WE ${ }^{45}$ należy interpretować w taki sposób, że osoba może, ze względu na przysługujące jej i przewidziane w art. 7 i 8 Karty praw podstawowych $\mathrm{UE}^{46}$ prawa, zażądać, aby dana informacja nie była już podawana do wiadomości szerokiego kręgu odbiorców przez zawarcie jej na liście wyników wyszukiwania. Taka sytuacja w ocenie TSUE nie ma jednak miejsca, jeśli ze szczególnych powodów, takich jak rola odgrywana przez tę osobę w życiu publicznym, należałoby uznać, że ingerencja w prawa podstawowe tej osoby jest uzasadniona nadrzędnym interesem tego kręgu odbiorców polegającym na posiadaniu, dzięki zawarciu na liście dostępu do danej informacji ${ }^{47}$.

\section{Podsumowanie}

Poglądy, dotyczące skutków zatarcia skazania i ich wpływu na dopuszczalność upublicznienia faktu popełnienia przestępstwa, za które skazanie uległo zatar-

45 Mimo że dyrektywa 95/46/WE Parlamentu Europejskiego oraz Rady z 24 października 1995 r. w sprawie ochrony osób fizycznych w zakresie przetwarzania danych osobowych oraz swobodnego przepływu tych danych, Dz.Urz. UE L 281 z 23 listopada 1995 r, s. 0031-0050, została zastąpiona przez RODO, ustalenia TSUE zachowują aktualność. Przepisy dotyczyły sprostowania, usunięcia lub zablokowania danych, których przetwarzanie było niezgodne z przepisami dyrektywy, szczególnie ze względu na niekompletność lub niedokładność danych.

46 Artykuł 7 stanowi, że każdy ma prawo do poszanowania życia prywatnego i rodzinnego, domu i komunikowania się. Artykuł 8 dotyczy ochrony danych osobowych. Zgodnie $\mathrm{z}$ ust. 1, każdy ma prawo do ochrony danych osobowych, które go dotyczą. Ust. 2 stanowi, że dane te muszą być przetwarzane rzetelnie w określonych celach i za zgodą osoby zainteresowanej lub na innej uzasadnionej podstawie przewidzianej ustawą. Każdy ma prawo dostępu do zebranych danych, które go dotyczą, i prawo do dokonania ich sprostowania. W myśl ust. 3 przestrzeganie tych zasad podlega kontroli niezależnego organu.

47 Wyrok TSUE z 13 maja 2014 r., sygn. akt C-131/12, Google Spain SL i Google Inc. vs. Agencia Española de Protección de Datos (AEPD) i Mario Costes González, http://curia. europa.eu/juris/document/document.jsf;jsessionid=6836DB555615AB50EFF2374D AD1CA911 ?text $=\&$ docid $=152065 \&$ pageIndex $=0 \&$ doclang $=P L \&$ mode $=1 \mathrm{st} \& \operatorname{dir}=\&$ oc $\mathrm{c}=$ first\&part=1\&cid=10037492; więcej na ten temat zob. R. Pawlik, Ewolucja instytucji zatarcia skazania $w$ polskim prawie karnym $z$ perspektywy european criminal records information system - zagadnienia wybrane, „Krakowskie Studia Międzynarodowe” 2014, t. XI, nr 1, https://repozytorium.ka.edu.pl/bitstream/handle/11315/23056/PAWLIK_Ewolucja_instytucji_zatarcia_skazania_2014.pdf?sequence=1\&isAllowed=y. 
ciu, są w orzecznictwie i piśmiennictwie niejednolite. Niemniej stwierdzić należy, że zatarcie skazania nie uchyla wyroku skazującego, nie stanowi też odpowiednika orzeczenia uniewinniającego ani nie przywraca całkowicie stanu istniejącego przed skazaniem. Z orzecznictwa sądowego wynika, że chociaż: w wyniku zatarcia skazania osoba skazana może się przedstawiać jako niekarana i jako taka powinna być traktowana, to w pewnych sytuacjach fakt wcześniejszego popełnienia przestępstwa może, a nawet powinien być uwzględniany, może więc być też ustalany i ujawniany w ramach realizacji konstytucyjnego prawa do informacji. Zdaniem sądów dopuszczalne jest przełamanie fikcji niekaralności w przypadku zatarcia skazania i ujawnienie informacji o tymże skazaniu, gdy przemawia za tym interes społeczny, znajdujący odbicie w konkretnych okolicznościach sprawy. Niezbędne będzie jednak każdorazowo wyważenie prawa do swobody wypowiedzi i informacji oraz prawa do ochrony dobrego imienia w drodze korzystania z dobrodziejstwa zatarcia skazania. Ujawnienie zatartego skazania nie może służyć stworzeniu sensacyjnej wiadomości, lecz wyłącznie zapewnieniu niezbędnej społeczeństwu informacji o rzeczywistym zagrożeniu ważnych wartości z powodu uzasadnionych obaw, że popełnione kiedyś przez tę osobę przestępstwo dowodzi takich jej właściwości, które powodują, że nie daje ona rękojmi właściwej realizacji wykonywanych zadań, ze względu na ich specyfikę, charakter, zakres uprawnień lub wątpliwą skuteczność sprawowanej nad nią kontroli.

W doktrynie prawa karnego przyjmuje się, że rozgłoszenie po zatarciu skazania faktu karalności, a także samego faktu zatarcia skazania, jako pośrednio informującego o wcześniejszym skazaniu, może stanowić przestępstwo zniesławienia. W przypadku postępowania osoby pełniącej funkcję publiczną odpowiedzialność za zniesławienie może wyłączyć prawdziwość postawionego zarzutu (art. 213 k.k.). Podanie niepełnej informacji - jedynie o skazaniu danej osoby, bez jednoczesnej informacji o zatarciu skazania - może z kolei stanowić naruszenie dóbr osobistych (art. 23 k.c.), w tym czci i godności poszkodowanego, jego dobrego imienia czy prawa do prywatności, co uprawnia do dochodzenia roszczeń w trybie art. 24 k.c.

\section{Bibliografia}

Błaszczyk M. [w:] Kodeks karny. Część ogólna. Komentarz. Art. 1-116, red. M. Królikowski, R. Zawłocki, Warszawa 2017.

Ferenc-Szydełko E., Prawo prasowe. Komentarz, 2013, LEX.

Gardocki L., Prawo karne, Warszawa 2004.

Kosmaty P., Zatarcie skazania a wolność wypowiedzi, www.rp.pl/Sady-i-prokuratura/ 3122499984-Piotr-Kosmaty.

Nowińska E., Wolność wypowiedzi prasowej, 2007, LEX. 
Papierkowski Z., Rehabilitacja, zatarcie skazania a zniesławienie, „Głos Sądownictwa” 1934.

Pawlik R., Ewolucja instytucji zatarcia skazania w polskim prawie karnym z perspektywy european criminal records information system - zagadnienia wybrane, „Krakowskie Studia Międzynarodowe" 2014, t. XI, nr 1.

Piekarski M., Ochrona czci osób zrehabilitowanych, „Państwo i Prawo” 1948, nr 11.

Sobczak J., Prawo prasowe. Komentarz, 2008, LEX.

Stefańska B.J., Glosa do wyroku SN z dnia 29 sierpnia 2013 r., IV KK 168/13, „Przegląd Sądowy" 2014, nr 6.

Stefańska B.J., Skutki zatarcia skazania, https://pk.gov.pl/wp-content/uploads/2013/12/ b26ffd0ce2b5b470aa577a03409f7884.doc.

Stefańska B.J., Ujawnienie zatartego skazania a przestępstwo zniesławienia [w:] Przestępstwa przeciwko czci i nietykalności cielesnej, red. M. Mozgawa, 2013, LEX.

Szczechowicz J., Prawne aspekty ochrony dóbr osobistych, http://uwm.edu.pl/mk.k.s/wp-content/uploads/12-szczechowicz.pdf.

Wilk L. [w:] Kodeks karny. Komentarz, t. 1, red. W. Wróbel, A. Zoll, Warszawa 2004.

Wojciechowski J., Kodeks karny z krótkim komentarzem praktycznym, Skierniewice 1992.

Wolter W., Zarys systemu prawa karnego. Część ogólna, t. II, Kraków 1993. 